\title{
Accuracy of novel diagnostic biomarkers for hepatocellular carcinoma: An update for clinicians (Review)
}

\author{
PATRICK REICHL and WOLFGANG MIKULITS \\ Department of Medicine I, Institute of Cancer Research, Comprehensive Cancer Center, \\ Medical University of Vienna, A-1090 Vienna, Austria
}

Received January 8, 2016; Accepted March 4, 2016

DOI: $10.3892 /$ or.2016.4842

\begin{abstract}
Hepatocellular carcinoma (HCC) is the most common liver malignancy and a leading cause of cancer-related mortality worldwide. Accurate detection and differential diagnosis of early HCC can significantly improve patient survival. Currently, detection of HCC in clinical practice is performed by diagnostic imaging techniques and determination of serum biomarkers, most notably $\alpha$-fetoprotein (AFP), fucosylated AFP and des- $\gamma$-carboxyprothrombin. However, these methods display limitations in sensitivity and specificity, especially with respect to early stages of HCC. Recently,

Correspondence to: Professor Wolfgang Mikulits, Department of Medicine I, Institute of Cancer Research, Comprehensive Cancer Center, Medical University of Vienna, Borschkegasse 8A, A-1090 Vienna, Austria

E-mail: wolfgang.mikulits@meduniwien.ac.at
\end{abstract}

Abbreviations: AASLD, American Association for the Study of Liver Disease; AFP, $\alpha$-fetoprotein; AFP-L3, fucosylated AFP; ALCAM, activated leukocyte cell adhesion molecule; AUC, area under the curve; BCLC, Barcelona Clinic Liver Cancer; CLD, chronic liver disease; ConA-pCD, concanavalin A binding pro-cathepsin D; DCP, des- $\gamma$-carboxyprothrombin; EASL, European Association for the Study of the Liver; EGF, epidermal growth factor; ELISA, enzyme-linked immunosorbent assay; EMT, epithelial to mesenchymal transition; FDA, Food and Drug Administration; GDF, growth and differentiation factor; HBV, hepatitis B virus; $\mathrm{HCC}$, hepatocellular carcinoma; HCV, hepatitis $\mathrm{C}$ virus; $\mathrm{LC}$, liver cirrhosis; miRNA, microRNA; LTBP, latent TGF- $\beta$ binding protein; MCM6, minichromosome maintenance complex component 6; MCP-1, monocyte chemoattractant protein-1; miR, microRNA; MMP, matrix metalloproteinase; NAFLD, non-alcoholic fatty liver disease; PON1, paraoxonase 1; PRDX3, peroxiredoxin 3; qMSP, quantitative methylation-specific PCR; qRT-PCR, quantitative reverse-transcription-polymerase chain reaction; RFA, radiofrequency ablation; ROC, receiver operating characteristic; sAxl, soluble Axl; TCF-4, T-cell factor-4; TGF, transforming growth factor; Trx1, thioredoxin; YB-1, Y-box binding protein 1

Key words: diagnostic biomarker, hepatocellular carcinoma, $\alpha$-fetoprotein, des- $\gamma$-carboxyprothrombin, annexin A2, soluble Axl, thioredoxin, minichromosome maintenance high-throughput technologies have elucidated many new pathways involved in hepatocarcinogenesis and have led to the discovery of a plethora of novel, non-invasive serum biomarkers. In particular, the combination of AFP with these new candidate molecules has yielded promising results. In this review, we aimed at recapitulating the most recent (2013-2015) developments in HCC biomarker research. We compared promising novel diagnostic serum protein biomarkers, such as annexin A2, the soluble form of the receptor tyrosine kinase Axl and thioredoxin, as well as their combinations with AFP. High diagnostic performance (area under the curve $>0.75$ ) as shown by threshold-independent receiver operating characteristic curve analysis was a prerequisite for inclusion in this review. In addition, we discuss the role and potential of microRNAs in HCC diagnosis and associated methodological challenges.

\section{Contents}

1. Current diagnosis of hepatocellular carcinoma

2. Novel serum proteins as biomarkers for $\mathrm{HCC}$

3. DNA methylation for $\mathrm{HCC}$ diagnosis

4. MicroRNAs to detect HCC

5. Conclusion

\section{Current diagnosis of hepatocellular carcinoma}

Hepatocellular carcinoma (HCC) is the most commonly diagnosed liver malignancy and the third leading cause of cancer-related mortality worldwide with rising incidence in Western countries $(1,2)$. In the past decades, HCC staging has been performed according to the Barcelona Clinic Liver Cancer (BCLC) criteria, which mainly rely on imaging techniques and define early and advanced-stage HCC with respect to tumor size and number of nodules (3). According to current guidelines of the European Association for the Study of the Liver (EASL) and the American Association for the Study of Liver Disease (AASLD), curative therapies are restricted to early-stage HCC patients only (4). These include liver resection or transplantation, as well as local radiofrequency ablation (RFA) and show a high 5-year survival rate of up to $70 \%$ (5). However, the majority of HCC 
patients are diagnosed at later stages, restricting therapeutic options to palliative treatment only and leading to a median survival of $<1$ year $(6,7)$. In this respect, transabdominal ultrasonography is currently the most commonly used tool for HCC detection and surveillance, primarily due to its cost-effectiveness. However, the sensitivity and specificity of ultrasound are highly dependent on operator experience as well as the patient's constitution, with obese patients representing a particular challenge. Furthermore, differential diagnosis of $\mathrm{HCC}$ vs. chronic cirrhosis of the liver is difficult and may not always be possible. All these factors contribute to the limited sensitivity of early HCC detection by ultrasonography, ranging from 32 to $65 \%(8,9)$. Thus, improved and more accurate detection of HCC at early stages, especially among high-risk groups, such as cirrhosis or hepatitis patients is highly desired.

The detection of biomarkers associated with HCC in body fluids or tissues is the most promising approach to improve diagnostic accuracy and to overcome the disadvantages of current diagnostic strategies. Especially non-invasive techniques relying on blood or serum samples would be beneficial for both patients and clinicians. In addition to ultrasonography, the determination of $\alpha$-fetoprotein (AFP) levels in serum is the gold standard in $\mathrm{HCC}$ detection and has been widely used to complement HCC surveillance (5). However, due to its low diagnostic accuracy, with sensitivities ranging from a mere $18-60 \%$ and a specificity of $\sim 85-90 \%$, AFP has recently been excluded from current AASLD HCC surveillance guidelines (4,8,10-13). In line, it has been shown that $80 \%$ of small HCC nodules do not display increased AFP levels and that the sensitivity of AFP for tumors smaller than $3 \mathrm{~cm}$ is restricted to $25 \%(14,15)$. Consequently, several other biomarkers have been suggested to complement AFP and increase the accuracy of HCC detection, most notably des- $\gamma$-carboxyprothrombin (DCP), lectin-bound AFP (AFP-L3\%), osteopontin (OPN), glypican 3 (GPC3) and Golgi protein-73 (GP73; Table I). However, reports concerning the performance of these markers are conflicting and a comprehensive meta-analysis has shown both DCP and AFP-L3\% to be inferior to AFP (16). Furthermore, combination of AFP with these markers only moderately increased diagnostic performance compared to AFP alone (16). For GPC3, available studies were also recently reviewed in a meta-analysis showing lower diagnostic performance as compared to AFP (17). OPN was evaluated in comparison with AFP in early-stage HCC patients and cirrhotic as well as chronic hepatitis B (HBV)-positive controls. In this study, OPN showed almost identical diagnostic performance as AFP (18). With regard to GP73, studies including AFP have been performed which employed various assay methods and applied variable cut-off values (16). Hence, further research is needed to validate these markers and additional candidates that are continuously emerging.

In this review, we discuss novel biomarkers derived from protein, DNA methylation as well as microRNAs (miRs) and their potential in the differential diagnosis between chronic liver diseases (CLDs), such as chronic hepatitis B or C (HBV, $\mathrm{HCV}$ ) infection or chronic hepatitis $\mathrm{C}(\mathrm{HCV})$ infection and liver cirrhosis (LC) vs. early-stage HCC. In particular, we focus on receiver operating characteristic (ROC) curves, generated by plotting sensitivity against the false-positive rate which represent a threshold-independent approach
Table I. Diagnostic value of current biomarkers for HCC compared to AFP.

\begin{tabular}{|c|c|c|c|c|}
\hline Marker & Ref. & Comparison & & AUC \\
\hline \multirow[t]{3}{*}{$\mathrm{DCP}$} & (16) & Mixed & $\mathrm{DCP}$ & 0.79 \\
\hline & & (meta-analysis) & AFP & 0.83 \\
\hline & & & Combined & 0.87 \\
\hline \multirow[t]{3}{*}{ AFP-L3\% } & (16) & Mixed & AFP-L3 & 0.71 \\
\hline & & (meta-analysis) & AFP & 0.83 \\
\hline & & & Combined & 0.83 \\
\hline \multirow[t]{3}{*}{ OPN } & (18) & Early-stage HCC & OPN & 0.78 \\
\hline & & vs. LC and CHB & AFP & 0.78 \\
\hline & & & Combined & 0.84 \\
\hline \multirow[t]{3}{*}{ GPC3 } & (17) & Mixed & GPC3 & 0.76 \\
\hline & & (meta-analysis) & AFP & 0.81 \\
\hline & & & Combined & 0.85 \\
\hline \multirow[t]{3}{*}{ GP73 } & (16) & Mixed & GP73 & 0.91 \\
\hline & & (meta-analysis) & AFP & 0.83 \\
\hline & & & Combined & 0.93 \\
\hline
\end{tabular}

AFP, $\alpha$-fetoprotein; AFP-L3\%, lectin-bound AFP; AUC, area under the curve; CHB, chronic hepatitis B; DCP, des- $\gamma$-carboxyprothrombin; GP73, Golgi protein-73; GPC3, glypican 3; HCC, hepatocellular carcinoma; LC, liver cirrhosis; OPN, osteopontin.

allowing the proper evaluation and comparison of different biomarkers (19). ROC curves and high corresponding areas under the curve (AUC) values ( $>0.75$ ), indicating significant diagnostic accuracy, were considered as a requirement for inclusion in this review in combination with significant patient and control numbers $(\mathrm{n}>50)$.

\section{Novel serum proteins as biomarkers for HCC}

Annexin A2. Annexin A2 belongs to the calcium-dependent, phospholipid-binding protein family and is located on the surface of endothelial and most epithelial cells (20). It was found to be dysregulated in many cancers, such as colon, lung, gastric, esophageal and breast carcinomas (21-26). In this respect, annexin A2 has been associated with tumor cell proliferation, apoptosis, transcriptional regulation, invasion, metastasis and angiogenesis (27). During hepatocarcinogenesis, annexin A2 expression is upregulated in cirrhotic liver tissue and malignant hepatocytes (28). Serum concentrations of annexin A2 have been suggested as a biomarker for HCC in 2009, but reliable studies have been missing to date (29). One group recently re-evaluated the usefulness of annexin A2 in serum samples from 175 HCCs of all stages, 23 hepatitis, 51 cirrhosis, 19 benign liver tumor patients and 49 healthy controls by enzyme-linked immunosorbent assay (ELISA; Table II) (30). Annexin A2 showed an AUC of 0.79 when comparing HCCs to healthy controls. Discrimination between HCC and grouped cirrhosis as well as benign liver tumor patients achieved an AUC of 0.80 . Unfortunately, sensitivity and specificity values were not stated for these comparisons. However, when limited 
to early HCC patients ( $\mathrm{n}=95)$ and cirrhotic controls $(\mathrm{n}=51)$, annexin A2 achieved an AUC of 0.80 with a sensitivity of $86.4 \%$ and a specificity of $73.5 \%$. Of note, early HCCs were defined as grouped BCLC stage 0 and A, which limits clinical usefulness considering the important differences in the therapeutic options between BCLC 0 and A patients.

$s A x l$. Axl is a receptor tyrosine kinase and belongs to the TAM family, which is comprised of Axl, Tyro3 and Mer. Axl is expressed in many cell types, including epithelial, mesenchymal and hematopoietic cells and its biological effects depend on cell and tissue context. Overexpression of Axl has been detected in several tumor types and correlates with poor disease outcome $(31,32)$. Binding of Axl by its ligand Gas6 activates a multitude of signaling pathways leading to enhanced proliferation, survival, invasion and metastasis. In HCC, Axl was shown to be upregulated and induced by Hippo/YAP signaling, enhancing invasion and lymphatic metastasis $(33,34)$. We recently discovered that $\mathrm{Axl}$ is also involved in TGF- $\beta$-mediated HCC progression by modulating TGF- $\beta$ signaling via activation of c-Jun N-terminal kinase and subsequent phosphorylation of Smad3 (35). Notably, Axl can be proteolytically processed, yielding an $80-\mathrm{kDa}$ soluble protein ( $\mathrm{AAxl}$ ), which is secreted into the extracellular space and can be detected in blood (36). We therefore investigated the potential of sAxl as a non-invasive biomarker of HCC in a multi-center study involving patients from China and Europe (Table II) (37). We collected serum samples from $311 \mathrm{HCC}$ patients of all stages, 30 cirrhotic and 125 healthy controls. Determination of sAxl levels by ELISA and subsequent ROC curve analysis yielded an AUC of 0.834 with a sensitivity of $78.1 \%$ and a specificity of $70.8 \%$ for all $\mathrm{HCC}$ vs. healthy controls. In differential diagnosis of HCC vs. liver cirrhosis, sAxl showed an AUC of 0.815 as well as sensitivities and specificities of 78 and $66.7 \%$, respectively. Importantly, analysis of patients with very early HCC, defined as BCLC $0(n=26)$ vs. cirrhotic controls gave an AUC of 0.838 with $80.8 \%$ sensitivity and $66.7 \%$ specificity. Furthermore, sAxl was able to distinguish AFP-negative HCC $(<20 \mathrm{ng} / \mathrm{ml}, \mathrm{n}=137)$ from liver cirrhosis with an AUC of $0.780,73 \%$ sensitivity and $66.7 \%$ specificity. Of note, sAxl values were not increased in breast $(n=10)$, ovarian $(n=10)$, or colorectal $(n=62)$ cancer patients with secondary hepatic malignancies.

Thioredoxin. Thioredoxin (Trx1) is a globular, oxidoreductase enzyme involved in the physiological defense against oxidative stress (38). In this context, Trx 1 is capable of reducing disulfide bonds of other proteins in the cytoplasm. However, it can play a different role, depending on its subcellular localization. When localized in the extracellular matrix, Trx1 acts as a chemokine, whereas in the nucleus, it can interact with many transcription factors, thereby regulating gene expression $(39,40)$. The role of Trx 1 in cancerogenesis is not yet fully understood, but it was shown to be upregulated in several tumor types. High Trx1 expression can stimulate cancer cell proliferation and angiogenesis through induction of HIF-1 $\alpha$, which in turn increases VEGF-A expression levels (41). Furthermore, upregulation of Trx1 in cancer cells has also been attributed to increased oxidative stress and may even exert a tumor-suppressive function (42). Overexpression of
Trx1 has been observed in HCC tissue samples and its levels correlate with tumor cell proliferation and metastasis $(43,44)$. A possible role of Trx 1 as a diagnostic serum marker for HCC was recently investigated by ELISA in a training cohort, comprising 180 HCCs of all stages, 120 cirrhosis, 120 CLD patients and 100 healthy controls (Table II) (45). ROC curve analysis of all HCC patients vs. all controls yielded an AUC of 0.946 with $84.3 \%$ sensitivity and $91.8 \%$ specificity. When the analysis was limited to all HCC vs. pooled LC and CLD patients, the resulting AUC was 0.901 with $78.2 \%$ sensitivity and $87.5 \%$ specificity. Importantly, the authors also performed an evaluation of very early HCCs $(n=38)$ against LC and CLD patients, resulting in an AUC of 0.844 with a sensitivity of $74.5 \%$ and a specificity of $86.7 \%$. The diagnostic performance was also assessed in a validation cohort of similar size, which showed very comparable results. Of note, very early HCCs were defined as well differentiated and smaller than $2 \mathrm{~cm}$. This does not fully comply with BCLC staging criteria, which do not take the histological grade into consideration, but rather includes the number of tumors nodules, vascular invasion and liver function (3).

CD147. CD147, also known as extracellular MMP inducer (EMMPRIN) or Basigin, is a member of the immunoglobulin superfamily and is thought to be involved in several cellular processes, such as intercellular recognition and spermatogenesis (46). CD147 is frequently overexpressed in several cancers, including HCC (47). Importantly, it is capable of inducing several matrix metalloproteinases (MMPs) and induction of MMP-2 and MMP-9 by CD147 can promote invasion and metastasis in HCC (48). Furthermore, membrane-bound CD147 was shown to interact with integrins, thereby modulating migration, invasion, colony formation and MMP secretion of HCC cells (49). Serum levels of soluble CD147 were determined in 62 HCC patients of all stages and 25 healthy controls by ELISA (Table II) (50). CD147 exhibited an AUC of 0.857 with a sensitivity of $83.9 \%$ and a specificity of $76.0 \%$. Notably, comparison of very early HCC (BCLC $0 ; n=12$ ) and healthy controls still gave an AUC of 0.85 with a sensitivity of $83.3 \%$.

CD166. CD166, also known as activated leukocyte cell adhesion molecule (ALCAM), is a transmembrane glycoprotein and belongs to the immunoglobulin superfamily, which was first described as a CD6 ligand on leukocytes (51). It is expressed in many cell types, particularly in immune and epithelial cells, as well as in hematopoietic or mesenchymal stem cells. Aberrant CD166 levels have been observed in colorectal, as well as breast and small cell lung cancer (52). In HCC, CD166 is induced by PI3K signaling and mediates anti-apoptotic effects (53). CD166 concentrations were assessed in sera of 51 HCC patients of unknown stage and 85 healthy controls by ELISA (Table II) (54). No further clinicopathological data were provided. CD166 showed an AUC of 0.986 with $100 \%$ sensitivity and $89.41 \%$ specificity. Of note, the authors also determined serum CD166 levels in HBV $(n=48), \operatorname{HCV}(n=40)$, cirrhosis $(n=41)$, gastric $(n=21)$, breast $(n=25)$ and lung $(n=21)$ cancer patients and found it exclusively elevated levels in HCC patients. Since no ROC curve analysis was performed, these findings require re-evaluation. 
Table II. Diagnostic value of novel biomarkers for HCC.

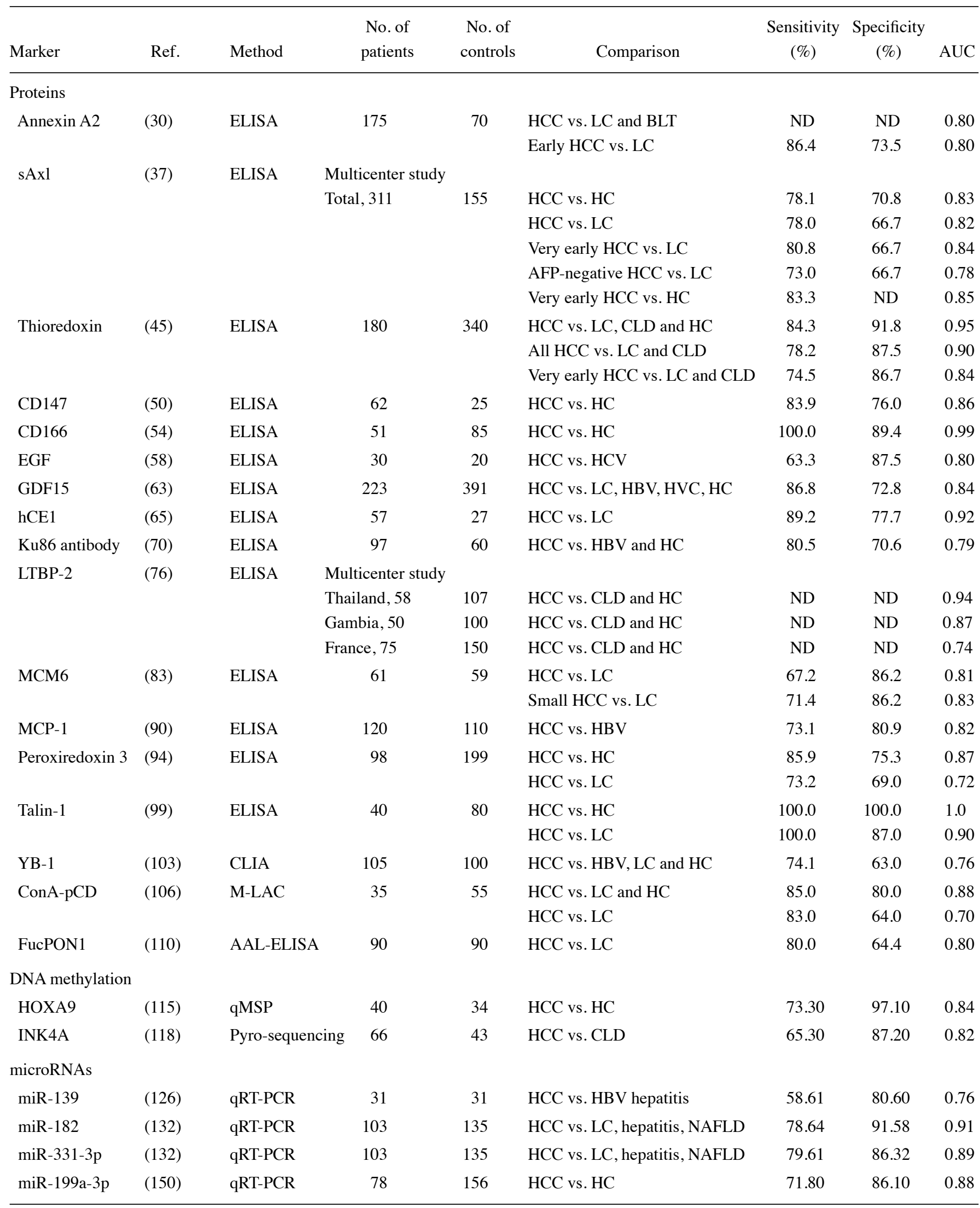

AAL, Aleuria aurantia lectin; AUC, area under the curve; BLT, benign liver tumor; hCE1, human carboxyesterase 1; CLD, chronic liver disease; CLIA, chemiluminescence immunoassay; ConA-pCD, concanavalin A binding procathepsin D; EGF, epidermal growth factor; ELISA, enzyme-linked immunosorbent assay; GDF15, growth and differentiation factor 15; HBV, hepatitis B virus; HC, healthy controls; HCC, hepatocellular carcinoma; HCV, hepatitis C virus; LC, liver cirrhosis; LTBP-2, latent TGF- $\beta$ binding protein-2; MCM6, minichromosome maintenance complex component 6; MCP-1, monocyte chemoattractant protein-1; M-LAC, multi-lectin affinity chromatography; NAFLD, non-alcoholic fatty liver disease; ND, not determined; PON1, paraoxonase 1; qMSP, quantitative methylation-specific PCR; qRT-PCR, quantitative reverse-transcriptase polymerase chain reaction; YB-1, Y-box binding protein 1. 
$E G F$. Epidermal growth factor (EGF) signaling is involved in the tumorigenesis of many cancers, including HCC. Alterations in serum EGF levels have been reported, with decreases in non-small cell lung and head and neck carcinomas (55). Increased EGF concentrations were observed in sera from pancreatic and thyroid cancer patients $(56,57)$. Its receptor, EGFR is considered as a major regulator of hepatocarcinogenesis by integrating several proliferation and survival signals. Evaluation of EGF concentrations was performed in sera of $20 \mathrm{HCV}$-positive controls as well as $30 \mathrm{HCC}$ patients by ELISA (Table II) (58). A sensitivity of $63.3 \%$, a specificity of $87.5 \%$ and a corresponding AUC of 0.80 were observed. Notably, EGF concentrations were not significantly increased in early HCC patients and no corresponding ROC curve analysis was performed.

GDF15. Growth differentiation factor 15 (GDF15), also known as macrophage inhibitory cytokine-1 belongs to the transforming growth factor (TGF)- $\beta$ superfamily (59). Under physiological conditions, it is exclusively expressed in placental tissue but can be induced in activated macrophages by pro-inflammatory cytokines, such as tumor necrosis factor- $\alpha$ and interleukin-6 (60). In this context, GDF15 may act in a negative autocrine feedback loop, since it suppresses the production of pro-inflammatory cytokines and inhibits the proliferation of blood mononuclear cells (61). Like TGF- $\beta 1$, GDF15 was shown to play contradictory roles in cancer development, inhibiting early cancerogenesis but promoting tumor progression at later stages (62). Its tumor-promoting effects, such as enhanced migration, angiogenesis or immunosuppression were demonstrated in malignant glioma, myeloma, glioblastoma, melanoma, prostate, gastric and breast cancer (61). In HCC, GDF15 was shown to be upregulated upon $\mathrm{HCV}$ infection and was recently investigated concerning its potential as a serum biomarker (Table II) (63). To this end, serum concentrations in 223 HCCs of all stages, 88 liver cirrhosis patients, $51 \mathrm{HBV}$ carriers, $50 \mathrm{HCV}$ carriers and 202 healthy controls were assessed by ELISA. Discrimination of HCC patients from all other conditions (LC, HBV, HCV and healthy controls) achieved an AUC of 0.843 with $86.8 \%$ sensitivity and $72.7 \%$ specificity. It has to be noted that GDF15 levels were equally elevated in cirrhosis patients and in $\mathrm{HCC}$, as compared to healthy controls. Thus, the diagnostic power for HCC vs. cirrhosis is anticipated to be low, limiting the usefulness of GDF15 for differential diagnosis of high-risk populations.

$h C E-1$. Human carboxylesterase 1 (hCE-1) is a serine esterase expressed in many tissues. It plays a role in the metabolism of xenobiotic compounds in the liver (64). A recent study explored its diagnostic performance by ELISA in 57 HCC patients of all stages and in 27 cirrhotic controls (Table II) (65). The analysis yielded a sensitivity of $89.2 \%$, a specificity of $77.7 \%$ and a corresponding AUC of 0.918 . Of note, 37 chronic hepatitis patients were also enrolled in the study but were excluded from this review due to the missing ROC curve analysis. Furthermore, HCC patients were grouped into early and advanced HCC and respective sensitivities and specificities were given. Again, without a threshold-independent approach (i.e., ROC curve analysis), a valid assessment of diagnostic performance was impossible.

Ku86 antibody. Ku86 (also known as Ku80), an ATP-dependent DNA helicase II, is part of the DNA-dependent protein kinase, which plays a key role in DNA repair via non-homologous end joining. More specifically, Ku86 dimerizes with Ku70 and binds to the ends of double-strand breaks, thereby acting as a scaffold to facilitate alignment and DNA repair by polymerases, nucleases and ligases (66). Interruption of these functions has been associated with chromosomal aberrations and tumor development in mice (67). In humans, development and progression of several gastrointestinal tumors, including liver cancer, have been linked to reduced Ku86 expression $(68,69)$. One recent study evaluated the occurrence of auto-antibodies against Ku86 by ELISA in 97 patients with HBV-related liver cancer, as well as 30 randomly chosen patients with HBV-related liver cirrhosis and 30 healthy subjects as controls (Table II) (70). The comparison of HCC and grouped healthy as well as cirrhotic controls yielded an AUC of 0.794 with sensitivity and specificity of 80.5 and $70.6 \%$, respectively.

LTBP-2 . Latent TGF- $\beta$ binding protein (LTBP)-2 belongs to the fibrillin family of extracellular matrix proteins. Unlike other LTBPs, it lacks a specific motif required for complex-formation with TGF- $\beta 1$ and its involvement in modulation of TGF- $\beta$ signaling remains unclear $(71,72)$. LTBP-2 was shown to be dysregulated in esophageal carcinoma, pancreatic ductal carcinoma and melanoma. In this respect, it affects cell adhesion and overexpression of LTBP-2 impairs colony formation in vitro. Paradoxically, high LTBP-2 levels correlate with poor patient outcome (73-75). It was recently suggested as a biomarker for $\mathrm{HCC}$ following mass spectrometric profiling (Table II) (76). LTBP-2 levels were subsequently determined in $183 \mathrm{HCC}, 274 \mathrm{CLD}$ (HBV- or HCV-positive) and 227 healthy controls from centers in Thailand (52 controls, 49 CLD, 58 HCC), Gambia (50 controls, 50 CLD, 50 HCC) and France ( 75 controls, 75 CLD, 75 HCC) by ELISA. Results yielded AUCs of $0.94,0.87$ and 0.74 for Thailand, Gambia and France, respectively. No distinction was made between different stages of HCC. ROC analyses of LTBP-2 vs. CLD patients were only shown for HCC patients or CLD controls exhibiting $<20 \mathrm{ng} / \mathrm{ml}$ AFP and the corresponding patient numbers were not indicated, rendering an evaluation impossible. However, as for healthy controls, a much lower AUC was obtained in samples from France (0.57) as compared to Thailand (0.98) or Gambia (0.85), even though CLD controls were selected from a similar etiological background (HBV- or HCV-positive). Therefore, the diagnostic usefulness of LTBP-2 as a biomarker of HCC remains unclear.

MCM6. Minichromosome maintenance complex component 6 (MCM6) is part of a multimeric protein complex involved in DNA synthesis and replication, specifically during initiation of S phase (77). Non-proliferating, somatic cells are devoid of MCM6 expression and upregulation of MCM family proteins has been associated with several cancers, including HCC (78-82) One group investigated the performance of MCM6 protein levels as a biomarker of HCC by ELISA in sera from $61 \mathrm{HCC}$ patients, including 14 small HCC cases (tumor 
size $<2 \mathrm{~cm}$ ), as well as 29 cirrhotic controls and 30 healthy controls (Table II) (83). In this respect, MCM6 showed an AUC of 0.81 when discriminating HCC from cirrhotic controls with a sensitivity of $67.2 \%$ and a specificity of $86.2 \%$. Notably, MCM6 exhibited an AUC of 0.825 in small HCCs vs. cirrhosis patients with sensitivity and specificity of 71.4 and $86.2 \%$, respectively. However, one drawback of this study is the missing classification of HCC patients into BCLC stages, which take, besides tumor size, additional clinicopathological parameters into account. Thus, a clear evaluation of MCM6 as a marker for very early HCC is an open issue.

MCP-1. Monocyte chemoattractant protein-1 (MCP-1) is a potent chemotactic factor for monocytes. It is secreted by a variety of cell types and can be induced by oxidative stress, growth factors or cytokines (84). MCP-1 is associated with enhanced tumor infiltration by tumor associated macrophages and enhanced angiogenesis in gastric and breast carcinomas as well as in meningioma (85-87). In HCC, MCP-1 expression correlates with disease progression (88). In particular, hepatic stellate cells and myofibroblasts, which play a crucial role in liver fibrosis and malignant transformation of parenchymal liver cells, secrete large amounts of MCP-1, thus promoting migration and invasion of hepatoma cells (89). One recent study discovered MCP-1 as a promising marker for HCC by determination of serum levels in 120 HCC patients of all stages and $110 \mathrm{HBV}$-carrying controls by ELISA (Table II) (90). ROC analysis yielded an AUC of 0.823 with a sensitivity and specificity of 73.1 and $80.9 \%$, respectively. Notably, samples were collected from patients who had previously undergone liver resection and were therefore designated as resectable. However, most patients included in this study exhibited advanced BCLC stages, which do not allow curative treatment such as liver resection.

Peroxiredoxin 3. Peroxiredoxin 3 (PRDX3) is a member of the peroxiredoxin protein family, involved in peroxide detoxification (91). It was shown to be overexpressed in mesothelioma, breast cancer, ovarian cancer and liver cancer (92). PRDX3 has also been suggested as a biomarker for HCC progression (93). One group recently investigated PRDX3 as a diagnostic biomarker in the sera of 98 Chinese HCC patients of all stages, 96 cirrhosis patients and 103 healthy controls by ELISA (Table II) (94). ROC analysis of HCC vs. healthy controls gave an AUC of 0.865 with a sensitivity of $85.9 \%$ and a specificity of $75.3 \%$. When HCCs were discriminated from liver cirrhosis patients, PRDX3 reached an AUC of 0.717 with $73.2 \%$ sensitivity and $69.0 \%$ specificity, limiting its potential for differential diagnosis among high-risk populations. Furthermore, different cut-off values for PRDX3 were applied for cirrhotic patients and healthy controls vs. HCC. In addition, AFP performance in cirrhosis vs. HCC patients was not analyzed, rendering a comparison impossible.

Talin-1. Talin-1 was first identified as a cytoplasmic binding partner of integrins, essential for cell adhesion and motility (95). In this respect, binding of Talin-1 to the cytoplasmic NPXY motif of $\beta$-integrin can lead to integrin activation and affect adhesion, spreading and motility (96). Talin expression has been linked to endometrial as well as prostate cancers $(97,98)$. Its potential as a biomarker for $\mathrm{HCC}$ was recently assessed by ELISA in a study including sera of $40 \mathrm{HCC}$ patients of all stages, 40 healthy as well as 40 cirrhotic controls (Table II) (99). Talin-1 exhibited 100\% sensitivity and specificity and an AUC of 1.0 in differentiating HCCs from healthy controls. Compared against cirrhotic controls, Talin-1 showed $100 \%$ sensitivity, $87 \%$ specificity and an AUC of 0.90 . The study also evaluated the performance of AFP in the same study population (sensitivity, $80 \%$ and specificity, $65 \%$ ). However, combination of Talin-1 with AFP strongly affected AUC as well as specificity, reducing them to 0.79 and 57\%, respectively. In addition, patient characteristics, such as BCLC stage, were not taken into account. Therefore, the suitability of Talin-1 as a tool for detection of early HCC remains uncertain.

$Y B-1$. Y-box binding protein 1 (YB-1) is a pleiotropic transcription/translation factor, belonging to the highly conserved cold-shock domain protein superfamily (100). YB-1 is overexpressed in many cancer types (101). Even though it is predominantly localized in the nucleus, where it is involved in DNA excision repair, it can also be actively secreted in the presence of cytokines and upon oxidative stress (102). One recent study investigated the diagnostic performance of YB-1 in 105 HCC patients of all stages vs. a control cohort comprising 25 HBV, 25 cirrhotic and 50 healthy subjects (Table II) (103). Determination of YB-1 serum concentrations was performed using a newly developed sandwich-type chemiluminescence immunoassay. YB-1 displayed an AUC of 0.764, with a sensitivity of $74.1 \%$ and a specificity of $63.0 \%$. Controls were only assessed in combination and no separate analyses of healthy, HBV-bearing or cirrhotic controls vs. HCCs were performed.

ConA- $p C D$. Alterations in N-linked glycosylation of several proteins have been reported in liver cancer patients $(104,105)$. In this context, the most prominent member of N-linked glycoproteins, AFP-L3\% has been intensely studied, ultimately resulting in its approval by the Food and Drug Administration (FDA) for HCC diagnosis in 2005. One recent study aimed at identifying additional $\mathrm{N}$-linked glycoproteins in HCC tissue and serum samples by multilectin affinity chromatography (Table II) (106). This led to the discovery of concanavalin A (ConA) binding procathepsin D (ConA-pCD) as a candidate biomarker. Serum samples from 35 HCC patients as well as 29 cirrhotic and 26 non-cirrhotic controls were further analyzed by western blotting, followed by ConA affinity chromatography. ROC curve analysis of HCC vs. all controls resulted in an AUC of 0.88 with a sensitivity of $85 \%$ and a specificity of $80 \%$. Analysis of HCC vs. cirrhotic controls yielded an AUC of 0.70 with sensitivity and specificity of 83 and $64 \%$, respectively.

Fucosylated PON1 (Fuc-PON1). Paraoxonase 1 (PON1) is a calcium-dependent hydrolase, capable of hydrolyzing and thereby detoxifying organophosphorous compounds (107). It is mainly expressed in the liver and secreted into the bloodstream. PON1 polymorphisms have been linked to the development of several malignancies, such as breast, lung and ovarian cancers as well as multiple myeloma (108). In HCC, its expression level was first established as a biomarker for microvascular invasion (109). Notably, PON1 is highly 
fucosylated in HCC tissues and its fucosylation status was recently investigated as a diagnostic biomarker by Aleuria aurantia lectin-dependent ELISA. Fuc-PON1 levels were determined in sera of 90 liver cirrhosis and $90 \mathrm{HCC}$ patients, all HBV-positive (Table II) (110). ROC analysis yielded an AUC of 0.803 with a sensitivity of $80.0 \%$ and a specificity of $64.4 \%$. Of note, the control group was also subdivided and diagnostic performance was separately assessed among AFP-positive and AFP-negative HCC. Here, Fuc-PON1 achieved a lower AUC in AFP-positive (>20 ng/ml) patients (0.788).

\section{DNA methylation for HCC diagnosis}

HOXA9. Homeobox protein HOXA9 is a member of the homeobox genes, which show precise spatial and temporal regulation during embryonic development and determine the body plan (111). Upon knock out, a reduction of myeloid progenitor cells was observed in mice. HOXA9 is also highly expressed in hematopoietic stem cells and its expression gradually decreases with increasing extent of differentiation $(112,113)$. HOXA9 expression is frequently dysregulated in several cancers. In this context, its expression was found to be increased in colorectal, ovarian and prostate cancer as well as in glioblastoma, whereas decreased expression through promoter methylation was observed in breast cancer (114). One recent study discovered hypermethylation of HOXA9 in HCC samples by array analysis (Table II) (115). Methylation of HOXA9 was subsequently assessed by quantitative methylation-specific PCR (qMSP) in plasma from $40 \mathrm{HCC}$ patients of all stages and 34 healthy controls. Statistical evaluation showed an AUC of 0.835 with $73.3 \%$ sensitivity and $97.1 \%$ specificity.

$p 16^{I N K 4 A} \cdot \mathrm{p} 16^{\mathrm{INK} 4 \mathrm{~A}}$ is crucial in cell cycle regulation and considered as a tumor-suppressor. It interacts with cyclin-dependent kinases, thereby inhibiting their ability to phosphorylate and inactivate the retinoblastoma protein, ultimately leading to cell cycle arrest (116). Promoter hypermethylation of p16 ${ }^{\mathrm{INK} 4 \mathrm{~A}}$ and subsequent reduction of $\mathrm{p} 16^{\mathrm{INK} 4 \mathrm{~A}}$ levels has been observed in a majority of HCC tissue samples (117). A recent study examined INK4A methylation via pyrosequencing, using circulating cell-free DNA from the blood samples of 66 HCC patients and 43 controls with chronic hepatitis and liver cirrhosis (Table II) (118). The sensitivity and specificity observed for INK4A methylation were 65.3 and $87.2 \%$, respectively, with an AUC of 0.82 .

\section{MicroRNAs to detect HCC}

miRs have received increasing attention as a new class of non-invasive biomarkers for many cancers, including HCC $(119,120)$. miRs are small non-coding RNA molecules, which play an important role in post-transcriptional regulation of gene expression by either mRNA degradation or by blocking translation initiation.Importantly, miRs can alsobe released into the blood stream as free molecules or bound to proteins. In this context, they display exceptional stability against endogenous RNAse activity, which renders them ideally suited for detection and quantification by quantitative reverse-transcription polymerase chain reaction (qRT-PCR) (121). Many miRs were shown to be dysregulated in liver cancer and especially miRNA signatures, comprised of three or more miRs have been suggested for highly accurate HCC detection (122). The most novel developments in this field are outlined below.

miR-139. miRNA-139 was shown to be aberrantly expressed in many cancers, including HCC. Notably, it can suppress epithelial-mesenchymal transition (EMT), migration and invasion in $\mathrm{HCC}$ via targeting of ZEB1 and ZEB2. Accordingly, it is downregulated in a majority of HCC tissue samples (123). miR-139 was also shown to reduce Rho-kinase 2 expression in HCC, thereby inhibiting migration, invasion and metastasis (124). Furthermore, it regulates proliferation and invasion of HCC cells by targeting T-cell factor (TCF)-4 mRNA, resulting in decreased $\beta$-catenin/TCF-4 transcriptional activity (125). This mechanism could also be involved in the suppression of EMT by miR-139. Thus, it is not surprising that miR-139 was recently investigated regarding its performance as a biomarker of HCC by qRT-PCR in sera of 31 HCC patients and 31 chronic HBV patients as controls (Table II) (126). The analysis showed a downregulation of miRNA-139 in HCC patients with an AUC of 0.761 , a specificity of $58.1 \%$ and a sensitivity of $80.6 \%$. However, clinicopathological and etiological characteristics were not defined.

miR-182. miR-182 belongs to a polycistronic cluster comprised of three miRNAs and located on chromosome 7. miR-182 is predominantly expressed in sensory organs such as the retina, the nose and the inner ear and shows a specific expression pattern during the development of these structures (127). miR-182 was shown to be overexpressed in breast carcinoma, melanoma, glioma, ovarian, prostate and colorectal cancers. In contrast, miR-182 plays a more ambiguous role in lung cancer, where overexpression of miRNA-182 was shown to inhibit cancerogenesis in vivo (128). In HCC, upregulation of miR-182 is associated with increased resistance to cisplatin as well as enhanced proliferation and invasive abilities (129-131). miR-182 was recently investigated as a candidate serological biomarker in serum samples of $103 \mathrm{HCC}$ patients of all stages, 95 CLD patients [39 patients with cirrhosis, 47 with chronic hepatitis and 9 with non-alcoholic fatty liver disease (NAFLD)] and 40 healthy controls by qRT-PCR (Table II) (132). ROC curve analysis showed an AUC of 0.911 for the discrimination between HCC and CLDs with a sensitivity of $78.6 \%$ and a specificity of $91.6 \%$.

miR-331-3p. miR-331-3p was first discovered during miR expression profiling of chronic and acute lymphocytic leukemia, along with one of its putative targets SOCS1 which regulates STAT activation enhancing cell survival and proliferation (133). miR-331-3p was subsequently shown to be dysregulated in several malignancies, such as prostate, lung, breast and gastric cancer as well as in glioblastoma. Notably, it is also involved in the induction of EMT in prostate cancer (134-138). In HCC, miR-331-3p was suggested as a possible prognostic marker and it was recently shown to promote proliferation and metastasis via targeting of the $\mathrm{PH}$ domain and leucine-rich repeat protein phosphatase $(139,140)$. The diagnostic potential of serum miR-331-3p was explored in the same cohort as described for miR-182 (Table II) (132). 
Table III. Diagnostic performance of promising markers in early-stage HCC patients vs. high-risk groups.

\begin{tabular}{|c|c|c|c|c|c|c|}
\hline Marker & Refs. & Comparison & & Sensitivity (\%) & Specificity (\%) & AUC \\
\hline \multirow{3}{*}{ Annexin A2 } & $(30)$ & Early HCC vs. LC & Annexin A2 & 86.4 & 73.5 & 0.80 \\
\hline & & & AFP & ND & ND & 0.66 \\
\hline & & & Combined & ND & ND & 0.83 \\
\hline \multirow[t]{3}{*}{ sAxl } & (37) & Very early HCC vs. LC & sAxl & 80.8 & 66.7 & 0.84 \\
\hline & & & AFP & 42.3 & 93.3 & 0.66 \\
\hline & & & Combined & 88.5 & 76.7 & 0.90 \\
\hline \multirow[t]{3}{*}{ Thioredoxin } & $(45)$ & Very early HCC vs. LC and CLD & Thioredoxin & 74.5 & 79.6 & 0.84 \\
\hline & & & AFP & 70.1 & 69.8 & 0.73 \\
\hline & & & Combined & 81.6 & 87.4 & 0.88 \\
\hline
\end{tabular}

AFP, $\alpha$-fetoprotein; AUC, area under the curve; CLD, chronic liver disease; HCC, hepatocellular carcinoma; LC, liver cirrhosis; ND, not determined.

In this context, miR-331-3p was upregulated and showed comparable diagnostic performance, with an AUC of 0.890 , a sensitivity of $79.6 \%$ and a specificity of $86.3 \%$ when discriminating HCC from CLDs.

$m i R-199 a-3 p$. Altered expression of miR-199a-3p has been shown in a variety of tumors, such as ovarian, breast, esophageal, colorectal and gastric cancer, as well as in osteosarcoma. In this respect, it was also suggested as a serum biomarker for colorectal carcinoma (141-147). Furthermore, both higher and lower expression levels have been observed in different tumor types as compared to normal tissue and accordingly, tumor-suppressive as well as tumor-promoting abilities of miR-199a-3p have been described. Notably, miR-199a-3p interferes with the expression of $\mathrm{Axl}$, thereby inhibiting the progression and metastasis of osteosarcoma (144). In HCC, miR-199a-3p regulates mTOR and c-Met signaling, thereby attenuating the invasive potential and increasing chemosensitivity. Accordingly, miR-199a-3p is often downregulated in human HCC (148). It targets CD44 and subsequently reduces proliferation in CD44-positive HCC cells (149). Decreased serum levels of miR-199a-3p were investigated for their diagnostic value in the sera of $78 \mathrm{HCC}$ patients of all stages and in 156 healthy controls by qRT-PCR (Table II) (150). ROC curve analysis yielded an AUC of 0.883 with $71.8 \%$ sensitivity and $86.1 \%$ specificity.

\section{Conclusion}

The clinicopathological and etiological characteristics specific for HCC represent a massive challenge for validating and establishing promising candidate biomarkers in clinical practice. HCC can develop in response to direct carcinogenic events, such as Aflatoxin $B_{1}$ adducts, but in the majority of cases, liver cancerogenesis is a multi-step process driven by chronic inflammation due to oxidative stress caused by HBV or HCV infection, alcohol abuse and/or NAFLD. These insults cause senescence of hepatocytes and concomitant activation of stellate cells, leading to fibrosis and ultimately cirrhosis of the liver, which is considered a pre-malignant state and the major risk factor for HCC (151). Thus, biomarkers permitting accurate differential diagnosis between cirrhotic and cancer patients are most desirable. Additionally, HCCs exhibit a vast genetic and pathological heterogeneity due to the variety of underlying CLDs, which must be especially considered when evaluating the performance of a biomarker. Furthermore, the accuracy of biomarkers must be viewed in light of the etiology as well as the respective controls since the prevalence of different etiologies shows great variation depending on the geography. Notably, HBV is the leading cause of HCC in Asia, whereas alcohol-, NAFLD- and HCV-induced HCCs are more prevalent in Western countries (152).

HCC detection at the earliest stage is of outmost relevance for anticancer therapy. The BCLC staging system classifies early HCC as a solitary tumor of up to three nodules, each below $3 \mathrm{~cm}$ in size within preserved liver functions (153). In these cases, curative therapeutic interventions by surgical resection, liver transplantation or percutaneous ablation show high 5-year survival rates. Yet, every 3-month waiting period for a liver transplant is expected to increase pre-transplantation mortality by $10 \%$. Furthermore, liver resection poses a risk of recurrence depending on tumor size and number $(5,154)$. In this respect, minimally invasive percutaneous ablation methods achieve complete tumor necrosis in $100 \%$ of solitary $\mathrm{HCC}<2 \mathrm{~cm}$, whereas the success rate is $70-80 \%$ in $\mathrm{HCC}<3 \mathrm{~cm}$ (5). Furthermore, a study examining 218 patients with tumors $<2 \mathrm{~cm}$ showed sustained responses following RFA in $97 \%$ of patients during the 31-month follow-up period (155). Therefore, HCC detection at the earliest stage, defined as BCLC 0 (a solitary tumor $<2 \mathrm{~cm}$ ) could minimize waiting periods and many risks associated with liver resection or transplantation. Thus, biomarkers showing high diagnostic power in both HCC detection and distinction from cirrhosis, while taking tumor stage and patient etiology into account, are the most promising. Annexin A2, MCM6, sAxl and thioredoxin were evaluated in early or very early HCCs vs. cirrhotic or CLD patients and achieved high AUCs. LTBP-2 and sAxl were also investigated in Eastern as well as Western patient populations. However, LTBP-2 exhibited a drop in diagnostic performance in European HCC patients and no independent comparison with cirrhotic controls was provided, whereas sAxl performed equally well in all populations examined. 
Moreover, most diagnostic strategies using serum samples rely on the combination of novel biomarkers with established ones, especially AFP, to increase diagnostic performance. In this context, annexin A2 showed a combined AUC of 0.83 for early HCC. In the case of sAxl and thioredoxin, combined AUCs of 0.901 and 0.875 were achieved for very early $\mathrm{HCC}(<2 \mathrm{~cm})$, respectively, emphasizing their potential clinical relevance (Table III) $(37,45)$. For thioredoxin and AFP, these results could be verified in a validation cohort, with a combined AUC of 0.870 . The authors also reported that $69.2 \%$ of AFP-negative patients were detectable by thioredoxin. However, no corresponding ROC analysis was performed (45). Although no matched validation cohort was evaluated for $\mathrm{SAxl}$ and its combination with AFP, it achieved high performance in all patient populations evaluated in the multicenter study. Furthermore, sAxl displayed a sensitivity of $86.7 \%$ and an AUC of 0.858 for very early, AFP-negative HCC, underlining its potential in complementing AFP (37). For MCM6, the combined AUC was not indicated, but the specificity dropped to $50.8 \%$ (83).

Although miRs exhibit exceptional diagnostic accuracy, several methodological limitations must be considered for this new class of HCC biomarkers. For example, sample collection and processing have a significant impact on the result of miR quantification, since platelets contain a wide spectrum of miRs, which may be released into the sample during coagulation (156). Thus, significant differences can arise between serum and plasma samples. The fasting status may further affect the miR status, as their carriers, such as proteins or lipoprotein particles, may be more or less abundant (157). Furthermore, different extraction methods can strongly bias the resulting miR levels and subsequent quantification (158). In addition, qRT-PCR analysis as the most common method of miR detection lacks universally accepted normalization controls (159). These restrictions currently limit the usability and reproducibility of miR data for the detection of HCC.

Despite increasing overall complexity, the availability of high throughput technologies has considerably improved our understanding of HCC pathogenesis. As a result, new molecules and strategies in $\mathrm{HCC}$ biomarker research are continuously emerging. The analysis of exosomes, small membranous vesicles of 30-100 $\mathrm{nm}$ in diameter, is among the most promising strategy in this respect. They are derived from multi-vesicular bodies and can be secreted into the extracellular space by most cell types, including HCC cells (160). Exosomes can transport a variety of molecules such as proteins, mRNAs and miRs (161). Although their discovery dates back to 1983, their potential as biomarkers for HCC has only been recently recognized (162). In rats, a combination of AFP, exosomes and circulating miRs (miR-10b, miR-21, miR-122 and miR-200a) detects HCC more accurately with an AUC of 0.943 as compared to AFP alone (AUC 0.826) (163). In humans, exosomal HCC-associated miR-21 increases in sera of HCC patients (164). Recently, another class of molecules has drawn attention in HCC research, namely long non-coding RNAs (lncRNAs). IncRNAs are longer than 200 nucleotides and are present in virtually all cell types, regulating gene expression via cis- and transacting mechanisms. In this regard, lncRNAs play significant roles in many cellular processes, such as chromatin remodeling, cell cycle control, apoptosis or cell fate specification.
Importantly, lncRNAs were shown to be dysregulated in HCC, promoting cell proliferation and tumor progression (165). In this context, a recent study investigated the expression profile of lncRNAs in the sera of HCC patients for its suitability as a biomarker (166). The authors discovered a significant increase in lncRNA-UCA1 and lncRNA-WRAP53 in HCC vs. healthy or HCV controls. This suggests that lncRNAs may represent an important new class of HCC biomarkers, in addition to miR and protein biomarkers.

\section{Acknowledgements}

The authors are grateful for the grant support by the Austrian Science Fund (FWF), P25356, and the Herzfelder Family Foundation.

\section{References}

1. Ferlay J, Shin HR, Bray F, Forman D, Mathers C and Parkin DM: Estimates of worldwide burden of cancer in 2008: GLOBOCAN 2008. Int J Cancer 127: 2893-2917, 2010.

2. Venook AP, Papandreou C, Furuse J and de Guevara LL: The incidence and epidemiology of hepatocellular carcinoma: A global and regional perspective. Oncologist 15 (Suppl 4): 5-13, 2010.

3. Llovet JM, Brú C and Bruix J: Prognosis of hepatocellular carcinoma: The BCLC staging classification. Semin Liver Dis 19: 329-338, 1999.

4. Bruix J and Sherman M; American Association for the Study of Liver Diseases: Management of hepatocellular carcinoma: An update. Hepatology 53: 1020-1022, 2011.

5. El-Serag HB, Marrero JA, Rudolph L and Reddy KR: Diagnosis and treatment of hepatocellular carcinoma. Gastroenterology 134: 1752-1763, 2008.

6. Altekruse SF, McGlynn KA and Reichman ME: Hepatocellular carcinoma incidence, mortality, and survival trends in the United States from 1975 to 2005. J Clin Oncol 27: 1485-1491, 2009.

7. Llovet JM, Bustamante J, Castells A, Vilana R, Ayuso MC, Sala M, Brú C, Rodés J and Bruix J: Natural history of untreated nonsurgical hepatocellular carcinoma: Rationale for the design and evaluation of therapeutic trials. Hepatology 29: 62-67, 1999.

8. Singal A, Volk ML, Waljee A, Salgia R, Higgins P, Rogers MA and Marrero JA: Meta-analysis: Surveillance with ultrasound for early-stage hepatocellular carcinoma in patients with cirrhosis. Aliment Pharmacol Ther 30: 37-47, 2009.

9. Singal AG, Conjeevaram HS, Volk ML, Fu S, Fontana RJ, Askari F, Su GL, Lok AS and Marrero JA: Effectiveness of hepatocellular carcinoma surveillance in patients with cirrhosis. Cancer Epidemiol Biomarkers Prev 21: 793-799, 2012.

10. Marrero JA, Feng Z, Wang Y, Nguyen MH, Befeler AS, Roberts LR, Reddy KR, Harnois D, Llovet JM, Normolle D, et al: Alpha-fetoprotein, des-gamma carboxyprothrombin, and lectin-bound alpha-fetoprotein in early hepatocellular carcinoma. Gastroenterology 137: 110-118, 2009.

11. Mao Y, Yang H, Xu H, Lu X, Sang X, Du S, Zhao H, Chen W, $\mathrm{Xu}$ Y, Chi T, et al: Golgi protein 73 (GOLPH2) is a valuable serum marker for hepatocellular carcinoma. Gut 59: 1687-1693, 2010.

12. Farinati F, Marino D, De Giorgio M, Baldan A, Cantarini M, Cursaro C, Rapaccini G, Del Poggio P, Di Nolfo MA, Benvegnù L, et al: Diagnostic and prognostic role of alpha-fetoprotein in hepatocellular carcinoma: Both or neither? Am J Gastroenterol 101: 524-532, 2006.

13. Lok AS, Sterling RK, Everhart JE, Wright EC, Hoefs JC, Di Bisceglie AM, Morgan TR, Kim HY, Lee WM, Bonkovsky HL, et al; HALT-C Trial Group: Des-gamma-carboxy prothrombin and alpha-fetoprotein as biomarkers for the early detection of hepatocellular carcinoma. Gastroenterology 138: 493-502, 2010.

14. Saffroy R, Pham P, Reffas M, Takka M, Lemoine A and Debuire B: New perspectives and strategy research biomarkers for hepatocellular carcinoma. Clin Chem Lab Med 45: 1169-1179, 2007. 
15. Chen DS, Sung JL, Sheu JC, Lai MY, How SW, Hsu HC, Lee CS and Wei TC: Serum alpha-fetoprotein in the early stage of human hepatocellular carcinoma. Gastroenterology 86: 1404-1409, 1984.

16. Hu B, Tian X, Sun J and Meng X: Evaluation of individual and combined applications of serum biomarkers for diagnosis of hepatocellular carcinoma: A meta-analysis. Int J Mol Sci 14: 23559-23580, 2013

17. Jia X, Liu J, Gao Y, Huang Y and Du Z: Diagnosis accuracy of serum glypican-3 in patients with hepatocellular carcinoma: A systematic review with meta-analysis. Arch Med Res 45 580-588, 2014

18. Ge T, Shen Q, Wang N, Zhang Y, Ge Z, Chu W, Lv X, Zhao F, Zhao W, Fan J, et al: Diagnostic values of alpha-fetoprotein dickkopf-1, and osteopontin for hepatocellular carcinoma. Med Oncol 32: 59, 2015.

19. Warnock DG and Peck CC: A roadmap for biomarker qualification. Nat Biotechnol 28: 444-445, 2010.

20. Sharma MC and Sharma M: The role of annexin II in angiogenesis and tumor progression: A potential therapeutic target. Curr Pharm Des 13: 3568-3575, 2007.

21. Emoto K, Sawada H, Yamada Y, Fujimoto H, Takahama Y, Ueno M, Takayama T, Uchida H, Kamada K, Naito A, et al: Annexin II overexpression is correlated with poor prognosis in human gastric carcinoma. Anticancer Res 21: 1339-1345, 2001.

22. Qi YJ, He QY, Ma YF, Du YW, Liu GC, Li YJ, Tsao GS, Ngai SM and Chiu JF: Proteomic identification of malignant transformation-related proteins in esophageal squamous cell carcinoma. J Cell Biochem 104: 1625-1635, 2008.

23. Alfonso P, Cañamero M, Fernández-Carbonié F, Núñez A and Casal JI: Proteome analysis of membrane fractions in colorectal carcinomas by using 2D-DIGE saturation labeling. J Proteome Res 7: 4247-4255, 2008

24. Yao H, Zhang Z, Xiao Z, Chen Y, Li C, Zhang P, Li M, Liu Y, Guan Y, Yu Y,et al: Identification of metastasis associated proteins in human lung squamous carcinoma using two-dimensional difference gel electrophoresis and laser capture microdissection. Lung Cancer 65: 41-48, 2009.

25. Sharma MR, Koltowski L, Ownbey RT, Tuszynski GP and Sharma MC: Angiogenesis-associated protein annexin II in breast cancer: Selective expression in invasive breast cancer and contribution to tumor invasion and progression. Exp Mol Pathol 81: 146-156, 2006.

26. Zhao P, Zhang W, Wang SJ, Yu XL, Tang J, Huang W, Li Y, Cui HY, Guo YS, Tavernier J, et al: HAb18G/CD147 promotes cell motility by regulating annexin II-activated RhoA and Rac1 signaling pathways in hepatocellular carcinoma cells. Hepatology 54: 2012-2024, 2011.

27. Lokman NA, Ween MP, Oehler MK and Ricciardelli C: The role of annexin A2 in tumorigenesis and cancer progression. Cancer Microenviron 4: 199-208, 2011.

28. Yu GR, Kim SH, Park SH, Cui XD, Xu DY, Yu HC, Cho BH, Yeom YI, Kim SS, Kim SB, et al: Identification of molecular markers for the oncogenic differentiation of hepatocellular carcinoma. Exp Mol Med 39: 641-652, 2007.

29. Ji NY, Park MY, Kang YH, Lee CI, Kim DG, Yeom YI, Jang YJ, Myung PK, Kim JW, Lee HG, et al: Evaluation of Annexin II as a potential serum marker for hepatocellular carcinoma using a developed sandwich ELISA method. Int J Mol Med 24: 765-771, 2009.

30. Sun Y, Gao G, Cai J, Wang Y, Qu X, He L, Liu F, Zhang Y, Lin K, Ma S, et al: Annexin A2 is a discriminative serological candidate in early hepatocellular carcinoma. Carcinogenesis 34: 595-604, 2013.

31. Axelrod $\mathrm{H}$ and Pienta KJ: Axl as a mediator of cellular growth and survival. Oncotarget 5: 8818-8852, 2014.

32. Paccez JD, Vogelsang M, Parker MI and Zerbini LF: The receptor tyrosine kinase Axl in cancer: Biological functions and therapeutic implications. Int J Cancer 134: 1024-1033, 2014.

33. Tsou AP, Wu KM, Tsen TY, Chi CW, Chiu JH, Lui WY, Hu CP, Chang C, Chou CK and Tsai SF: Parallel hybridization analysis of multiple protein kinase genes: Identification of gene expression patterns characteristic of human hepatocellular carcinoma. Genomics 50: 331-340, 1998 .

34. Xu MZ, Chan SW, Liu AM, Wong KF, Fan ST, Chen J, Poon RT, Zender L, Lowe SW, Hong W, et al: AXL receptor kinase is a mediator of YAP-dependent oncogenic functions in hepatocellular carcinoma. Oncogene 30: 1229-1240, 2011.
35. Reichl P, Dengler M, van Zijl F, Huber H, Führlinger G, Reichel C, Sieghart W, Peck-Radosavljevic M, Grubinger M and Mikulits W: Axl activates autocrine transforming growth factor- $\beta$ signaling in hepatocellular carcinoma. Hepatology 61 : 930-941, 2015.

36. Ekman C, Stenhoff J and Dahlbäck B: Gas6 is complexed to the soluble tyrosine kinase receptor Axl in human blood. J Thromb Haemost 8: 838-844, 2010.

37. Reichl P, Fang M, Starlinger P, Staufer K, Nenutil R, Muller P, Greplova K, Valik D, Dooley S, Brostjan C, et al: Multicenter analysis of soluble Axl reveals diagnostic value for very early stage hepatocellular carcinoma. Int J Cancer 137: 385-394, 2015.

38. Laurent TC, Moore EC and Reichard P: Enzymatic synthesis of deoxyribonucleotides. IV. Isolation and characterization of thioredoxin, the hydrogen donor from Escherichia Coli B. J Biol Chem 239: 3436-3444, 1964

39. Nordberg J and Arnér ES: Reactive oxygen species, antioxidants, and the mammalian thioredoxin system. Free Radic Biol Med 31: $1287-1312,2001$

40. Mahmood DF, Abderrazak A,ElHadri K, Simmet T and Rouis M: The thioredoxin system as a therapeutic target in human health and disease. Antioxid Redox Signal 19: 1266-1303, 2013.

41. Kaimul AM, Nakamura H, Masutani $\mathrm{H}$ and Yodoi J: Thioredoxin and thioredoxin-binding protein-2 in cancer and metabolic syndrome. Free Radic Biol Med 43: 861-868, 2007.

42. Arnér ES and Holmgren A: The thioredoxin system in cancer. Semin Cancer Biol 16: 420-426, 2006

43. Mollbrink A, Jawad R, Vlamis-Gardikas A, Edenvik P, Isaksson B, Danielsson O, Stål P and Fernandes AP: Expression of thioredoxins and glutaredoxins in human hepatocellular carcinoma: Correlation to cell proliferation, tumor size and metabolic syndrome. Int J Immunopathol Pharmacol 27: 169-183, 2014.

44. Cunnea P, Fernandes AP, Capitanio A, Eken S, Spyrou G and Björnstedt $\mathrm{M}$ : Increased expression of specific thioredoxin family proteins; a pilot immunohistochemical study on human hepatocellular carcinoma. Int J Immunopathol Pharmacol 20: 17-24, 2007.

45. Li J, Cheng ZJ, Liu Y, Yan ZL, Wang K, Wu D, Wan XY, Xia Y, Lau WY, Wu MC, et al: Serum thioredoxin is a diagnostic marker for hepatocellular carcinoma. Oncotarget 6: 9551-9563, 2015

46. Yurchenko V, Constant S and Bukrinsky M: Dealing with the family: CD147 interactions with cyclophilins. Immunology 117: 301-309, 2006

47. Weidle UH, Scheuer W, Eggle D, Klostermann S and Stockinger H: Cancer-related issues of CD147. Cancer Genomics Proteomics 7: 157-169, 2010.

48. Xu J, Xu HY, Zhang Q, Song F, Jiang JL, Yang XM, Mi L, Wen N, Tian R, Wang L, et al: HAb18G/CD147 functions in invasion and metastasis of hepatocellular carcinoma. Mol Cancer Res 5: 605-614, 2007.

49. Li Y, Wu J, Song F, Tang J, Wang SJ, Yu XL, Chen ZN and Jiang JL: Extracellular membrane-proximal domain of HAb18G/CD147 binds to metal ion-dependent adhesion site (MIDAS) motif of integrin $\beta 1$ to modulate malignant properties of hepatoma cells. J Biol Chem 287: 4759-4772, 2012

50. Wu J, Hao ZW, Zhao YX, Yang XM, Tang H, Zhang X, Song F, Sun XX, Wang B, Nan G, et al: Full-length soluble CD147 promotes MMP-2 expression and is a potential serological marker in detection of hepatocellular carcinoma. J Transl Med 12: 190, 2014.

51. Bowen MA, Patel DD, Li X, Modrell B, Malacko AR, Wang WC, Marquardt H, Neubauer M,Pesando JM,Francke U, et al: Cloning, mapping, and characterization of activated leukocyte-cell adhesion molecule (ALCAM), a CD6 ligand. J Exp Med 181: 2213-2220, 1995

52. Weidle UH, Eggle D, Klostermann S and Swart GW: ALCAM/CD166: Cancer-related issues. Cancer Genomics Proteomics 7: 231-243, 2010.

53. Ma L, Wang J, Lin J, Pan Q, Yu Y and Sun F: Cluster of differentiation 166 (CD166) regulated by phosphatidylinositide 3-kinase (PI3K)/AKT signaling to exert its anti-apoptotic role via yes-associated protein (YAP) in liver cancer. J Biol Chem 289: 6921-6933, 2014.

54. Ma L, Lin J, Qiao Y, Weng W, Liu W, Wang J and Sun F: Serum CD166: A novel hepatocellular carcinoma tumor marker. Clin Chim Acta 441: 156-162, 2015.

55. Nedvídková J, Němec J, Stolba P, Vavrejnová V and Bednár J: Epidermal growth factor (EGF) in serum of patients with differentiated carcinoma of thyroids. Neoplasma 39: 11-14, 1992. 
56. Meggiato T, Plebani M, Basso D, Panozzo MP and Del Favero G: Serum growth factors in patients with pancreatic cancer. Tumour Biol 20: 65-71, 1999.

57. Konturek A, Barczyński M, Cichoń S, Pituch-Noworolska A Jonkisz J and Cichon W: Significance of vascular endothelial growth factor and epidermal growth factor in development of papillary thyroid cancer. Langenbecks Arch Surg 390: 216-221, 2005.

58. Shehata F, Abdel Monem N, Sakr M, Kasem S and Balbaa M: Epidermal growth factor, its receptor and transforming growth factor- $\beta 1$ in the diagnosis of $\mathrm{HCV}$-induced hepatocellular carcinoma. Med Oncol 30: 673, 2013.

59. Bootcov MR, Bauskin AR, Valenzuela SM, Moore AG, Bansal M He XY, Zhang HP, Donnellan M, Mahler S, Pryor K, et al: MIC-1, a novel macrophage inhibitory cytokine, is a divergent member of the TGF-beta superfamily. Proc Natl Acad Sci USA 94: 11514-11519, 1997.

60. Fairlie WD, Zhang H, Brown PK, Russell PK, Bauskin AR and Breit SN: Expression of a TGF-beta superfamily protein, macrophage inhibitory cytokine-1, in the yeast Pichia pastoris. Gene 254: 67-76, 2000.

61. Corre J, Hébraud B and Bourin P: Concise review: growth differentiation factor 15 in pathology: a clinical role? Stem Cells Transl Med 2: 946-952, 2013.

62. Eling TE, Baek SJ, Shim M and Lee CH: NSAID activated gene (NAG-1), a modulator of tumorigenesis. J Biochem Mol Biol 39: 649-655, 2006

63. Liu X, Chi X, Gong Q, Gao L, Niu Y, Chi X, Cheng M, Si Y, Wang M, Zhong J, et al: Association of serum level of growth differentiation factor 15 with liver cirrhosis and hepatocellular carcinoma. PLoS One 10: e0127518, 2015.

64. Satoh T and Hosokawa M: Structure, function and regulation of carboxylesterases. Chem Biol Interact 162: 195-211, 2006.

65. Na K, Jeong SK, Lee MJ, Cho SY, Kim SA, Lee MJ, Song SY, $\mathrm{Kim} \mathrm{H}, \mathrm{Kim} \mathrm{KS}$, Lee HW, et al: Human liver carboxylesterase 1 outperforms alpha-fetoprotein as biomarker to discriminate hepatocellular carcinoma from other liver diseases in Korean patients. Int J Cancer 133: 408-415, 2013.

66. Fell VL and Schild-Poulter C: The Ku heterodimer: Function in DNA repair and beyond. Mutat Res Rev Mutat Res 763: 15-29, 2015

67. Tong WM, Cortes U, Hande MP, Ohgaki H, Cavalli LR, Lansdorp PM, Haddad BR and Wang ZQ: Synergistic role of $\mathrm{Ku} 80$ and poly(ADP-ribose) polymerase in suppressing chromosomal aberrations and liver cancer formation. Cancer Res 62 : 6990-6996, 2002.

68. Nomura F, Sogawa K, Noda K, Seimiya M, Matsushita K, Miura T, Tomonaga T, Yoshitomi H, Imazeki F, Takizawa H, et al: Serum anti-Ku86 is a potential biomarker for early detection of hepatitis $\mathrm{C}$ virus-related hepatocellular carcinoma. Biochem Biophys Res Commun 421: 837-843, 2012.

69. Lim JW, Kim H and Kim KH: Expression of Ku70 and Ku80 mediated by NF-kappa B and cyclooxygenase- 2 is related to proliferation of human gastric cancer cells. J Biol Chem 277 46093-46100, 2002.

70. Xu Y, Liu AJ, Gao YX, Hu MG, Zhao GD, Zhao ZM and Liu R: Expression of Ku86 and presence of Ku86 antibody as biomarkers of hepatitis B virus related hepatocellular carcinoma. Dig Dis Sci 59: 614-622, 2014.

71. Morén A, Olofsson A, Stenman G, Sahlin P, Kanzaki T, Claesson-Welsh L, ten Dijke P, Miyazono K and Heldin CH: Identification and characterization of LTBP-2, a novel latent transforming growth factor-beta-binding protein. J Biol Chem 269: 32469-32478, 1994

72. Saharinen J and Keski-Oja J: Specific sequence motif of 8-Cys repeats of TGF-beta binding proteins, LTBPs, creates a hydrophobic interaction surface for binding of small latent TGF-beta. Mol Biol Cell 11: 2691-2704, 2000.

73. Chan SH, Yee Ko JM, Chan KW, Chan YP, Tao Q, Hyytiainen M, Keski-Oja J, Law S, Srivastava G, Tang J, et al: The ECM protein LTBP-2 is a suppressor of esophageal squamous cell carcinoma tumor formation but higher tumor expression associates with poor patient outcome. Int J Cancer 129: 565-573, 2011.

74. Vehviläinen P, Hyytiäinen M and Keski-Oja J: Latent transforming growth factor-beta-binding protein 2 is an adhesion protein for melanoma cells. J Biol Chem 278: 24705-24713, 2003.

75. Turtoi A, Musmeci D, Wang Y, Dumont B, Somja J, Bevilacqua G, De Pauw E, Delvenne P and Castronovo V: Identification of novel accessible proteins bearing diagnostic and therapeutic potential in human pancreatic ductal adenocarcinoma. J Proteome Res 10: 4302-4313, 2011
76. da Costa AN, Plymoth A, Santos-Silva D, Ortiz-Cuaran S, Camey S, Guilloreau P, Sangrajrang S, Khuhaprema T, Mendy M, Lesi OA, et al: Osteopontin and latent-TGF $\beta$ binding-protein 2 as potential diagnostic markers for HBV-related hepatocellular carcinoma. Int J Cancer 136: 172-181, 2015.

77. Lindner K, Gregán J, Montgomery S and Kearsey SE: Essential role of MCM proteins in premeiotic DNA replication. Mol Biol Cell 13: 435-444, 2002.

78. Blow JJ and Hodgson B: Replication licensing-defining the proliferative state? Trends Cell Biol 12: 72-78, 2002

79. Davies RJ, Freeman A, Morris LS, Bingham S, Dilworth S, Scott I, Laskey RA, Miller R and Coleman N: Analysis of minichromosome maintenance proteins as a novel method for detection of colorectal cancer in stool. Lancet 359: 1917-1919, 2002.

80. Ayaru L, Stoeber K, Webster GJ, Hatfield AR, Wollenschlaeger A, Okoturo O, Rashid M, Williams G and Pereira SP: Diagnosis of pancreaticobiliary malignancy by detection of minichromosome maintenance protein 5 in bile aspirates. Br J Cancer 98: $1548-1554,2008$.

81. Gauchotte G, Vigouroux C, Rech F, Battaglia-Hsu SF, Soudant M, Pinelli C, Civit T, Taillandier L, Vignaud JM and Bressenot A: Expression of minichromosome maintenance MCM6 protein in meningiomas is strongly correlated with histologic grade and clinical outcome. Am J Surg Pathol 36: 283-291, 2012.

82. Zhou YM, Zhang XF, Cao L, Li B, Sui CJ, Li YM and Yin ZF: MCM7 expression predicts post-operative prognosis for hepatocellular carcinoma. Liver Int 32: 1505-1509, 2012.

83. Zheng T, Chen M, Han S, Zhang L, Bai Y, Fang X, Ding SZ and Yang Y: Plasma minichromosome maintenance complex component 6 is a novel biomarker for hepatocellular carcinoma patients. Hepatol Res 44: 1347-1356, 2014.

84. Deshmane SL, Kremlev S, Amini S and Sawaya BE: Monocyte chemoattractant protein-1 (MCP-1): An overview. J Interferon Cytokine Res 29: 313-326, 2009.

85. Sato K, Kuratsu J, Takeshima H, Yoshimura T and Ushio Y: Expression of monocyte chemoattractant protein-1 in meningioma. J Neurosurg 82: 874-878, 1995.

86. Ohta M, Kitadai Y, Tanaka S, Yoshihara M, Yasui W, Mukaida N, Haruma K and Chayama K: Monocyte chemoattractant protein-1 expression correlates with macrophage infiltration and tumor vascularity in human gastric carcinomas. Int J Oncol 22: 773-778, 2003.

87. Valković T, Dobrila F, Melato M, Sasso F, Rizzardi C and Jonjić N: Correlation between vascular endothelial growth factor, angiogenesis, and tumor-associated macrophages in invasive ductal breast carcinoma. Virchows Arch 440: 583-588, 2002.

88. Dagouassat M, Suffee N, Hlawaty H, Haddad O, Charni F, Laguillier C, Vassy R, Martin L, Schischmanoff PO, Gattegno L, et al: Monocyte chemoattractant protein-1 (MCP-1)/CCL2 secreted by hepatic myofibroblasts promotes migration and invasion of human hepatoma cells. Int $\mathbf{J}$ Cancer 126: 1095-1108, 2010

89. Marra F, DeFranco R, Grappone C, Milani S, Pastacaldi S, Pinzani M, Romanelli RG, Laffi $G$ and Gentilini P: Increased expression of monocyte chemotactic protein-1 during active hepatic fibrogenesis: Correlation with monocyte infiltration. Am J Pathol 152: 423-430, 1998.

90. Wang WW, Ang SF, Kumar R, Heah C, Utama A, Tania NP, Li H, Tan SH, Poo D, Choo SP, et al: Identification of serum monocyte chemoattractant protein-1 and prolactin as potential tumor markers in hepatocellular carcinoma. PLoS One 8: e68904, 2013.

91. Dietz KJ, Horling F, König J and Baier M: The function of the chloroplast 2-cysteine peroxiredoxin in peroxide detoxification and its regulation. J Exp Bot 53: 1321-1329, 2002.

92. Huh JY, Kim Y, Jeong J, Park J, Kim I, Huh KH, Kim YS, Woo HA, Rhee SG, Lee KJ, et al: Peroxiredoxin 3 is a key molecule regulating adipocyte oxidative stress, mitochondrial biogenesis, and adipokine expression. Antioxid Redox Signal 16: 229-243, 2012

93. Qiao B, Wang J, Xie J, Niu Y, Ye S, Wan Q and Ye Q: Detection and identification of peroxiredoxin 3 as a biomarker in hepatocellular carcinoma by a proteomic approach. Int J Mol Med 29: 832-840, 2012.

94. Shi L, Wu LL, Yang JR, Chen XF, Zhang Y, Chen ZQ, Liu CL, Chi SY, Zheng JY, Huang HX, et al: Serum peroxiredoxin3 is a useful biomarker for early diagnosis and assessment of prognosis of hepatocellular carcinoma in Chinese patients. Asian Pac J Cancer Prev 15: 2979-2986, 2014. 
95. Horwitz A, Duggan K, Buck C, Beckerle MC and Burridge K Interaction of plasma membrane fibronectin receptor with talin-a transmembrane linkage. Nature 320: 531-533, 1986.

96. Tadokoro S, Shattil SJ, Eto K, Tai V, Liddington RC, de Pereda JM, Ginsberg MH and Calderwood DA: Talin binding to integrin beta tails: A final common step in integrin activation. Science 302: 103-106, 2003.

97. Slater M, Cooper M and Murphy CR: The cytoskeletal proteins alpha-actinin, Ezrin, and talin are de-expressed in endometriosis and endometrioid carcinoma compared with normal uterine epithelium. Appl Immunohistochem Mol Morphol 15: 170-174, 2007.

98. Sakamoto S, McCann RO, Dhir R and Kyprianou N: Talin1 promotes tumor invasion and metastasis via focal adhesion signaling and anoikis resistance. Cancer Res 70: 1885-1895, 2010

99. Youns MM, Abdel Wahab AH, Hassan ZA and Attia MS: Serum talin-1 is a potential novel biomarker for diagnosis of hepatocellular carcinoma in Egyptian patients. Asian Pac J Cancer Prev 14: 3819-3823, 2013.

100. Kohno K, Izumi H, Uchiumi T, Ashizuka M and Kuwano M: The pleiotropic functions of the Y-box-binding protein, YB-1. BioEssays 25: 691-698, 2003

101. Kuwano M, Oda Y, Izumi H, Yang SJ, Uchiumi T, Iwamoto Y, Toi M, Fujii T, Yamana H, Kinoshita H, et al: The role of nuclear Y-box binding protein 1 as a global marker in drug resistance. Mol Cancer Ther 3: 1485-1492, 2004.

102. Frye BC, Halfter S, Djudjaj S, Muehlenberg P, Weber S, Raffetseder U, En-Nia A, Knott H, Baron JM, Dooley S, et al: Y-box protein-1 is actively secreted through a non-classical pathway and acts as an extracellular mitogen. EMBO Rep 10 783-789, 2009.

103.Pu L, Jing S, Bianqin G, Ping L, Qindong L, Chenggui L, Feng C, Wenbin K, Qin W, Jinyu D, et al: Development of a chemiluminescence immunoassay for serum YB-1 and its clinical application as a potential diagnostic marker for hepatocellular carcinoma. Hepat Mon 13: e8918, 2013

104. Comunale MA, Wang M, Hafner J, Krakover J, Rodemich L, Kopenhaver B, Long RE, Junaidi O, Bisceglie AM, Block TM, et al: Identification and development of fucosylated glycoproteins as biomarkers of primary hepatocellular carcinoma. J Proteome Res 8: 595-602, 2009.

105. Na K, Lee EY, Lee HJ, Kim KY, Lee H, Jeong SK, Jeong AS, Cho SY, Kim SA, Song SY, et al: Human plasma carboxylesterase 1, a novel serologic biomarker candidate for hepatocellular carcinoma. Proteomics 9: 3989-3999, 2009.

106. Qi YJ, Ward DG, Pang C, Wang QM, Wei W, Ma J, Zhang J, Lou Q, Shimwell NJ, Martin A, et al: Proteomic profiling of $\mathrm{N}$-linked glycoproteins identifies ConA-binding procathepsin D as a novel serum biomarker for hepatocellular carcinoma. Proteomics 14: 186-195, 2014

107. Costa LG, Cole TB, Vitalone A and Furlong CE: Measurement of paraoxonase (PON1) status as a potential biomarker of susceptibility to organophosphate toxicity. Clin Chim Acta 352: $37-47,2005$

108. Goswami B, Tayal D, Gupta N and Mallika V: Paraoxonase: A multifaceted biomolecule. Clin Chim Acta 410: 1-12, 2009.

109. Huang C, Wang Y, Liu S, Ding G, Liu W, Zhou J, Kuang M, Ji Y, Kondo $\mathrm{T}$ and Fan J: Quantitative proteomic analysis identified paraoxonase 1 as a novel serum biomarker for microvascular invasion in hepatocellular carcinoma. J Proteome Res 12 1838-1846, 2013.

110. Zhang S, Jiang K, Zhang Q, Guo K and Liu Y: Serum fucosylated paraoxonase 1 as a potential glycobiomarker for clinical diagnosis of early hepatocellular carcinoma using ELISA Index Glycoconj J 32: 119-125, 2015.

111. Chisaka O and Capecchi MR: Regionally restricted developmental defects resulting from targeted disruption of the mouse homeobox gene hox-1.5. Nature 350: 473-479, 1991

112. Argiropoulos B and Humphries RK: Hox genes in hematopoiesis and leukemogenesis. Oncogene 26: 6766-6776, 2007.

113. So CW, Karsunky H, Wong P, Weissman IL and Cleary ML: Leukemic transformation of hematopoietic progenitors by MLL-GAS7 in the absence of Hoxa7 or Hoxa9. Blood 103 3192-3199, 2004.

114. Bhatlekar S, Fields JZ and Boman BM: HOX genes and their role in the development of human cancers. J Mol Med Berl 92: 811-823, 2014
115. Kuo CC, Lin CY, Shih YL, Hsieh CB, Lin PY, Guan SB, Hsieh MS, Lai HC, Chen CJ and Lin YW: Frequent methylation of HOXA9 gene in tumor tissues and plasma samples from human hepatocellular carcinomas. Clin Chem Lab Med 52: 1235-1245, 2014.

116. Li J, Poi MJ and Tsai MD: Regulatory mechanisms of tumor suppressor P16 ${ }^{\mathrm{INK} 4 \mathrm{~A}}$ and their relevance to cancer. Biochemistry 50: 5566-5582, 2011.

117. Zang JJ, Xie F, Xu JF, Qin YY, Shen RX, Yang JM and He J: P16 gene hypermethylation and hepatocellular carcinoma: A systematic review and meta-analysis. World J Gastroenterol 17: 3043-3048, 2011.

118. Huang G, Krocker JD, Kirk JL, Merwat SN, Ju H, Soloway RD, Wieck LR, Li A, Okorodudu AO, Petersen JR, et al: Evaluation of INK4A promoter methylation using pyrosequencing and circulating cell-free DNA from patients with hepatocellular carcinoma. Clin Chem Lab Med 52: 899-909, 2014.

119. Berindan-Neagoe I, Monroig PC, Pasculli B and Calin GA: MicroRNAome genome: A treasure for cancer diagnosis and therapy. CA Cancer J Clin 64: 311-336, 2014

120. Giordano S and Columbano A: MicroRNAs: New tools for diagnosis, prognosis, and therapy in hepatocellular carcinoma? Hepatology 57: 840-847, 2013.

121. Tutar L, Tutar E and Tutar Y: MicroRNAs and cancer; an overview. Curr Pharm Biotechnol 15: 430-437, 2014.

122. Anwar SL and Lehmann U: MicroRNAs: Emerging novel clinical biomarkers for hepatocellular carcinomas. J Clin Med 4: 1631-1650, 2015

123. Qiu G, Lin Y, Zhang H and Wu D: miR-139-5p inhibits epithelial-mesenchymal transition, migration and invasion of hepatocellular carcinoma cells by targeting ZEB1 and ZEB2. Biochem Biophys Res Commun 463: 315-321, 2015.

124. Wong CC, Wong CM, Tung EK, Au SL, Lee JM, Poon RT, Man K and Ng IO: The microRNA miR-139 suppresses metastasis and progression of hepatocellular carcinoma by down-regulating Rho-kinase 2. Gastroenterology 140: 322-331, 2011.

125. Gu W, Li X and Wang J: miR-139 regulates the proliferation and invasion of hepatocellular carcinoma through the WNT/TCF-4 pathway. Oncol Rep 31: 397-404, 2014.

126. Li T, Yin J, Yuan L, Wang S, Yang L, Du X and Lu J: Downregulation of microRNA-139 is associated with hepatocellular carcinoma risk and short-term survival. Oncol Rep 31: 16991706,2014

127. Xu S, Witmer PD, Lumayag S, Kovacs B and Valle D: MicroRNA (miRNA) transcriptome of mouse retina and identification of a sensory organ-specific miRNA cluster. J Biol Chem 282: 25053-25066, 2007

128. Wei Q, Lei R and Hu G: Roles of miR-182 in sensory organ development and cancer. Thorac Cancer 6: 2-9, 2015.

129.Zhang QH, Sun HM, Zheng RZ, Li YC, Zhang Q, Cheng P, Tang ZH and Huang F: Meta-analysis of microRNA-183 family expression in human cancer studies comparing cancer tissues with noncancerous tissues. Gene 527: 26-32, 2013.

130. Qin J, Luo M, Qian H and Chen W: Upregulated miR-182 increases drug resistance in cisplatin-treated $\mathrm{HCC}$ cell by regulating TP53INP1. Gene 538: 342-347, 2014.

131. Wang TH, Yeh CT, Ho JY, Ng KF and Chen TC: OncomiR miR-96 and miR-182 promote cell proliferation and invasion through targeting ephrinA5 in hepatocellular carcinoma. Mol Carcinog 55: 366-375, 2016

132. Chen L, Chu F, Cao Y, Shao J and Wang F: Serum miR-182 and miR-331-3p as diagnostic and prognostic markers in patients with hepatocellular carcinoma. Tumour Biol 36: 7439-7447, 2015.

133. Zanette DL, Rivadavia F, Molfetta GA, Barbuzano FG, ProtoSiqueira R, Silva-Jr WA, Falcão RP and Zago MA: miRNA expression profiles in chronic lymphocytic and acute lymphocy tic leukemia. Braz J Med Biol Res 40: 1435-1440, 2007.

134.Epis MR, Giles KM, Barker A, Kendrick TS and Leedman PJ: miR-331-3p regulates ERBB-2 expression and androgen receptor signaling in prostate cancer. J Biol Chem 284: 24696-24704, 2009.

135. Guo X, Guo L, Ji J, Zhang J, Zhang J, Chen X, Cai Q, Li J, Gu Q, Liu B, et al: miRNA-331-3p directly targets E2F1 and induces growth arrest in human gastric cancer. Biochem Biophys Res Commun 398: 1-6, 2010.

136. Nymark P, Guled M, Borze I, Faisal A, Lahti L, Salmenkivi K, Kettunen E, Anttila S and Knuutila S: Integrative analysis of microRNA, mRNA and aCGH data reveals asbestos- and histology-related changes in lung cancer. Genes Chromosomes Cancer 50: 585-597, 2011. 
137.Epis MR, Giles KM, Candy PA, Webster RJ and Leedman PJ: miR-331-3p regulates expression of neuropilin-2 in glioblastoma. J Neurooncol 116: 67-75, 2014.

138. Leivonen SK, Sahlberg KK, Mäkelä R, Due EU, Kallioniemi O, Børresen-Dale AL and Perälä M: High-throughput screens identify microRNAs essential for HER 2 positive breast cancer cell growth. Mol Oncol 8: 93-104, 2014.

139. Sukata T, Sumida K, Kushida M, Ogata K, Miyata K, Yabushita S and Uwagawa S: Circulating microRNAs, possible indicators of progress of rat hepatocarcinogenesis from early stages. Toxicol Lett 200: 46-52, 2011.

140. Chang RM, Yang $\mathrm{H}$, Fang $\mathrm{F}, \mathrm{Xu} J \mathrm{~J}$ and Yang LY: MicroRNA-331-3p promotes proliferation and metastasis of hepatocellular carcinoma by targeting $\mathrm{PH}$ domain and leucine-rich repeat protein phosphatase. Hepatology 60: 1251-1263, 2014.

141. Marchini S, Cavalieri D, Fruscio R, Calura E, Garavaglia D, Fuso Nerini I, Mangioni C, Cattoretti G, Clivio L, Beltrame L, et al: Association between miR-200c and the survival of patients with stage I epithelial ovarian cancer: A retrospective study of two independent tumour tissue collections. Lancet Oncol 12: 273-285, 2011

142. Bockmeyer CL, Christgen M, Müller M, Fischer S, Ahrens P, Länger F, Kreipe H and Lehmann U: MicroRNA profiles of healthy basal and luminal mammary epithelial cells are distinct and reflected in different breast cancer subtypes. Breast Cancer Res Treat 130: 735-745, 2011.

143. Wan D, He S, Xie B, Xu G, Gu W, Shen C, Hu Y, Wang X, Zhi Q and Wang L: Aberrant expression of miR-199a-3p and its clinical significance in colorectal cancers. Med Oncol 30: 378, 2013.

144. Tian R, Xie X, Han J, Luo C, Yong B, Peng H, Shen J and Peng T: miR-199a-3p negatively regulates the progression of osteosarcoma through targeting AXL. Am J Cancer Res 4: 738-750, 2014

145.Zhao X, He L, Li T, Lu Y, Miao Y, Liang S, Guo H, Bai M, Xie H, Luo G, et al: SRF expedites metastasis and modulates the epithelial to mesenchymal transition by regulating miR-199a-5p expression in human gastric cancer. Cell Death Differ 21: 1900-1913, 2014.

146. Feber A, Xi L, Pennathur A, Gooding WE, Bandla S, Wu M, Luketich JD, Godfrey TE and Litle VR: MicroRNA prognostic signature for nodal metastases and survival in esophageal adenocarcinoma. Ann Thorac Surg 91: 1523-1530, 2011.

147. Nonaka R, Nishimura J, Kagawa Y, Osawa H, Hasegawa J, Murata K, Okamura S, Ota H, Uemura M, Hata T, et al: Circulating miR-199a-3p as a novel serum biomarker for colorectal cancer. Oncol Rep 32: 2354-2358, 2014.

148.Fornari F, Milazzo M, Chieco P, Negrini M, Calin GA, Grazi GL, Pollutri D, Croce CM, Bolondi L and Gramantieri L: MiR-199a-3p regulates mTOR and c-Met to influence the doxorubicin sensitivity of human hepatocarcinoma cells. Cancer Res 70: 5184-5193, 2010.

149. Henry JC, Park JK, Jiang J, Kim JH, Nagorney DM, Roberts LR, Banerjee S and Schmittgen TD: miR-199a-3p targets CD44 and reduces proliferation of $\mathrm{CD} 44$ positive hepatocellular carcinoma cell lines. Biochem Biophys Res Commun 403: 120-125, 2010.

150. Yin J, Hou P, Wu Z, Wang T and Nie Y: Circulating miR-375 and miR-199a-3p as potential biomarkers for the diagnosis of hepatocellular carcinoma. Tumour Biol 36: 4501-4507, 2015.

151. Nault JC: Pathogenesis of hepatocellular carcinoma according to aetiology. Best Pract Res Clin Gastroenterol 28: 937-947, 2014.
152.El-Serag HB and Rudolph KL: Hepatocellular carcinoma: Epidemiology and molecular carcinogenesis. Gastroenterology 132: 2557-2576, 2007.

153. Forner A, Gilabert M, Bruix J and Raoul JL: Treatment of intermediate-stage hepatocellular carcinoma. Nat Rev Clin Oncol 11: 525-535, 2014

154. Ryu M, Shimamura Y, Kinoshita T, Konishi M, Kawano N, Iwasaki M, Furuse J, Yoshino M, Moriyama N and Sugita M: Therapeutic results of resection, transcatheter arterial embolization and percutaneous transhepatic ethanol injection in 3225 patients with hepatocellular carcinoma: A retrospective multicenter study. Jpn J Clin Oncol 27: 251-257, 1997.

155. Livraghi T, Meloni F, Di Stasi M, Rolle E, Solbiati L, Tinelli C and Rossi S: Sustained complete response and complications rates after radiofrequency ablation of very early hepatocellular carcinoma in cirrhosis: Is resection still the treatment of choice? Hepatology 47: 82-89, 2008.

156. Wang K, Yuan Y, Cho JH, McClarty S, Baxter D and Galas DJ: Comparing the MicroRNA spectrum between serum and plasma. PLoS One 7: e41561, 2012.

157. Vickers KC, Palmisano BT, Shoucri BM, Shamburek RD and Remaley AT: MicroRNAs are transported in plasma and delivered to recipient cells by high-density lipoproteins. Nat Cell Biol 13: 423-433, 2011.

158. Moldovan L, Batte KE, Trgovcich J, Wisler J, Marsh CB and Piper M: Methodological challenges in utilizing miRNAs as circulating biomarkers. J Cell Mol Med 18: 371-390, 2014.

159. Peltier HJ and Latham GJ: Normalization of microRNA expression levels in quantitative RT-PCR assays: Identification of suitable reference RNA targets in normal and cancerous human solid tissues. RNA 14: 844-852, 2008.

160. Qu Z, Jiang C, Wu J and Ding Y: Exosomes as potent regulators of HCC malignancy and potential bio-tools in clinical application. Int J Clin Exp Med 8: 17088-17095, 2015.

161. Xiao D, Ohlendorf J, Chen Y, Taylor DD, Rai SN, Waigel S, Zacharias W, Hao H and McMasters KM: Identifying mRNA, microRNA and protein profiles of melanoma exosomes. PLoS One 7: e46874, 2012

162. Harding C and Stahl P: Transferrin recycling in reticulocytes: $\mathrm{pH}$ and iron are important determinants of ligand binding and processing. Biochem Biophys Res Commun 113: 650-658, 1983.

163. Liu WH, Ren LN, Wang X, Wang T, Zhang N, Gao Y, Luo H, Navarro-Alvarez $\mathrm{N}$ and Tang LJ: Combination of exosomes and circulating microRNAs may serve as a promising tumor marker complementary to alpha-fetoprotein for early-stage hepatocellular carcinoma diagnosis in rats. J Cancer Res Clin Oncol 141: 1767-1778, 2015.

164. Wang H, Hou L, Li A, Duan Y, Gao H and Song X: Expression of serum exosomal microRNA-21 in human hepatocellular carcinoma. BioMed Res Int 2014: 864894, 2014.

165.Liu YR, Tang RX, Huang WT, Ren FH, He RQ, Yang LH, Luo DZ, Dang YW and Chen G: Long noncoding RNAs in hepatocellular carcinoma: Novel insights into their mechanism. World J Hepatol 7: 2781-2791, 2015

166. Kamel MM, Matboli M, Sallam M, Montasser IF, Saad AS and El-Tawdi AH: Investigation of long noncoding RNAs expression profile as potential serum biomarkers in patients with hepatocellular carcinoma. Transl Res 168: 134-145, 2016. 